\title{
The legacy of Dr Earl Russell
}

\section{A new era of pain medicine at Western University and Canada's first pain medicine residency program}

Sandra Botros

\section{ABSTRACT}

Dr Earl Russell (1920-2008) was a Canadian anesthetist and pain specialist who spent the majority of his career as a Western University faculty member and a pain physician in Southwestern Ontario. Dr Russell obtained his medical degree at Western, graduating in the class of 1950, and went on to serve in the Korean War as a medical officer. It was in Korea that he began developing a keen interest in pain medicine, using self-taught anesthesia skills to help soldiers suffering from frostbite. He returned to Canada and focused the rest of his career on the practice and advancement of pain medicine, and endowed the Earl Russell Chair in Pain Management in order to fund future research and education in the field. This article highlights the importance of his contributions to the field, in particular through his creation of the Earl Russell Chair, and how this led to the first Pain Medicine residency program in Canada at Western University.

\section{INTRODUCTION AND EARLY LIFE}

Dr Earl Russell grew up on a family farm in Saskatchewan during the Great Depression. From the age of 10, he dreamed of becoming a country doctor like the local general practitioner, who came around to tend to people's various needs, from setting broken bones to delivering babies. He credited the demanding work ethic of farm life for strengthening his dream, and managed a full-time workload on the farm throughout his elementary and high school education. ${ }^{1} \mathrm{He}$ went on to study math and physics at the University of Saskatchewan, and qualified for medical school before serving in World War II as an Officer in the Royal Canadian Signal Corps. Upon his return, he started medical school at the University of Saskatchewan, and completed his degree at the University of Western Ontario, graduating in $1950{ }^{2}$

Halfway through his intern year, he was sent to serve in the Korean War as a junior medical officer. He was placed with the 8055th Mobile Army Surgical Hospital (MASH) unit, which was the unit that inspired the popular television series, MASH. It was in Korea that Russell was thrown into the role of an anesthetist and developed his interest in pain medicine. It started one night when a surgeon approached him, asked "Do you know anything about anesthesia?" and recruited him to help with an appendectomy. From then on, anesthesia became his full-time role. His interest in pain management was sparked when he found himself deeply affected by the sight of wounded soldiers lying in the snow suffering from frostbite. This was a common occurrence, as soldiers often removed their gloves to fire their weapons. ${ }^{1}$ In an effort to relieve their pain, he taught himself to perform stellate ganglion blocks and many other anesthesia-related skills. ${ }^{2}$

\section{CAREER}

When he returned from Korea, Dr Russell completed his training in anesthesia at Kingston General Hospital. After being certified in 1955, he spent 10 years working in Kingston and teaching medical students at Queen's University. This included 2 years spent in Lagos, Nigeria, where he helped open the University of Lagos Medical School. He was recruited to Western's faculty in 1968 for his skills in chronic pain management and obstetrical analgesia. $\mathrm{He}$ worked in the anesthesia departments at both Victoria Hospital and St. Joseph's Hospital, and served as Chief of Anesthesia at Victoria Hospital. He was greatly respected and influential in several areas: these include establishing obstetrical epidurals as common practice in the early 1970s, many years before the rest of the country; and pioneering a telemedicine program that allowed doctors to see patients by video in Moose Factory, Ontario.,

In 1982, Dr Russell officially "retired" as a Professor Emeritus at Western, but continued to run his very busy pain clinics in Ingersoll and Newbury, Ontario. He was dedicated to his chronic pain patients and continued to see over 100 patients a week until the age of 87. He simultaneously ran his own farm near London, and worked on it himself until the age of $85 .^{2}$ Alongside his extensive professional accomplishments, he maintained a strong involvement within his church and the community throughout his life, and even established the Meals on Wheels program in London for seniors. ${ }^{1}$ When he died in 2008 at the age of 88, he left a lasting impression on the community of Southwestern Ontario. He is survived by his loving wife of 61 years, Marjorie, and his 4 children, 11 grandchildren, and 5 great-grandchildren. He was awarded a Distinguished Lifetime Achievement Award from the Canadian Pain Society in 2004 and an honorary Doctorate in Science from Western University in $2006 .{ }^{2}$

\section{LEGACY}

Although Dr Russell dedicated his life and career to his patients as a clinician rather than a researcher, he had a profound impact on the future of research in pain medicine. His most important contribution was his endowment of the Earl Russell Chair in Pain Management. Dr Russell had truly fallen in love with the art of pain management, and had hopeful visions for its future. In a 1999 interview, Russell predicted, "Pain is so devastating, and its management so primitive...I'll bet you in 10 or 15 years I just won't recognize it." 
The Earl Russell Chair in Pain Management is a position established at Western in 2002 by Dr Russell through a \$1.1 million donation. He donated another \$1.6 million in 2008. Initially, the Chair had two major mandates. The first was to direct a multidisciplinary pain management clinic in London, and the second was to advance research and education in the field. The first holder of the position (2001-2005) was Dr Patricia Morley-Forster, an anesthesiologist. The current Earl Russell Chair is Dr Dwight Moulin, a neurologist, who has held the position since 2005 , with the mandate now focused more on research and education. Both have been a driving force in making Dr Russell's dream a reality, and have described the lasting effects of Dr Russell's contribution on the field of pain medicine. ${ }^{3,4}$

Prior to the establishment of the Chair, research in the area was disconnected, with different specialties and disciplines separately initiating pain medicine research. These disciplines became united together under the support of the Earl Russell Chair and a multidisciplinary Scientific Advisory Board (with representation from anesthesiology, physiatry, rheumatology, psychology and neurology). The creation of this cohesive multidisciplinary program helped attract significant grant funding for research and pushed pain into the national spotlight. Several team members have held or hold CIHR grants. In addition, funding from the Canadian Foundation for Innovation and from the industry-established National Neuropathic Pain Patient Registry and Database has allowed for multiple studies addressing long-term outcomes of the management of neuropathic pain syndromes. Ultimately, this resulted in a surge of publications, detailed in the Annual Reports of the Western Pain Program. ${ }^{5}$ Emerging areas and relevant topics in the pain medicine program currently include functional MRI imaging, further studies on neuropathic pain, and the role of cannabinoids and lidocaine infusions in the management of chronic pain. ${ }^{3,4}$

Education has been another important focus, and was an area that Dr Russell recognized as vital to make the specialty more visible and attract more physicians. Pain education has historically been grossly underrepresented in medical school, despite the fact that it is the most common reason patients present to a doctor. Recently, Western has had substantial success in incorporating pain medicine into medical school and residency curriculums. This has come in the form of medical school lectures, resident half-days, monthly interdisciplinary pain rounds, and continuing medical education. Western was also the first medical school in Canada to offer a pain medicine selective; this has evolved into a mandatory core curriculum in pain assessment and management. Particular targets include the opioid epidemic and the role of opioid analgesics in the management of chronic pain.,

As a passionate clinician, Dr Russell wanted to ensure his endowment also directly improved clinical care in London. He envisioned one central multidisciplinary pain clinic, instead of smaller scattered ones. The creation of the Earl Russell Chair led to the opening of the St. Joseph's Pain Clinic, first directed by Dr Morley-Forster. The clinic moved to a new and larger location in 2012, and provides multidisciplinary care from several medical specialties as well as a coordinated team of psychologists, nurses, pharmacists, social workers, occupational therapists, and physiotherapists. There is considerable demand for pain management care, and the clinic has a sizeable wait list, so this remains an exciting area of future growth as the specialty of pain medicine gains popularity. ${ }^{3,4}$

The most significant accomplishment to come from Dr Russell's legacy has been the creation of the first Pain Medicine residency program in the country, which was officially recognized by the Royal College of Physicians and Surgeons of Canada in 2014. This 2-year fellowship program at Western, which can be entered from any discipline, was a huge step forward for the specialty of Pain Medicine at a national level and for Western's pain management program. The creation of the residency program was spearheaded by Dr Morley-Forster, who has worked towards this goal with the Royal College since 2006. She credited in part the connections and experience she gained as the holder of the Earl Russell Chair to make this a reality. ${ }^{3}$ Other universities have steadily followed in subsequent years, with eight programs having completed, or in the final phases of accreditation. Dr Geoff Bellingham, from the Department of Anaesthesiology and Perioperative Medicine, was the first Director of a Pain Medicine residency program in Canada, and he continues in that position at Western.

\section{CONCLUSION}

Dr Russell was an invaluable member of the Western faculty and he influenced the entire field of pain medicine. He was also a vital and irreplaceable part of the life of each patient he touched, and he worked tirelessly through his life to alleviate their suffering. His patients, the London community, and the Canadian medical community as a whole have been lucky to have him. As quoted from Dr Russell's 2006 speech at the Western convocation ceremony, showing where his heart truly lay in the practice of medicine, "In the sick room 10 cents worth of human understanding equals $\$ 10$ worth of science." ${ }^{6}$

\section{REFERENCES}

1. Mcfarlane A. Dr Earl Russell: A Life Dedicated to Easing Pain; "I'm The Boy They Call for Pain”. The London Free Press. 1999 Aug 22: Sect. B:1.

2. Morley-Forster PK. Dr Earl Stuart Russell. Pain Research \& Management: The Journal of the Canadian Pain Society [Internet]. 2008 Nov [cited 11 Dec 2016];13(6):462.

3. Morley-Forster PK. (Western University, London, Ontario). Telephone communication to: Sandra Botros (Western University, London, Ontario). 2016 Dec 11.

4. Moulin DE. (Western University, London, Ontario). Telephone communication to: Sandra Botros (Western University, London, Ontario). 2016 Dec 12.

5. Western Pain Medicine Program [Internet]. London: Annual Reports of the Western Pain Program; 2009-2015 [cited 2018 Jan 25]; Available from: www. westernpain.ca/research/annual-reports.

6. Russell E. Western University 2006 Convocation Address. London (ON): Western University, Department of Communication and Public Affairs; 2006 June 12 [cited 2017 Nov 18]. Available from: http://atwestern.typepad.com/ convocation_addresses/2006/06/june_12_pm_earl.html. 